\title{
First record of Dysmicoccus boninsis Kuwana, 1909 (Hemiptera: Pseudococcidae) on sugarcane in the state of Rio Grande do Sul
}

\author{
V. S. Sturzaa* (D) A. L. B. G. Perontib (D) and D. E. Navac \\ aUniversidade Federal de Pelotas - UFPel, Programa de Pós-graduação em Fitossanidade, Capão do Leão, RS, Brasil \\ •Universidade Estadual Paulista “Júlio de Mesquita Filho" - UNESP, Faculdade de Ciências Agrárias e Veterinárias, Jaboticabal, SP, Brasil \\ 'Embrapa Clima Temperado, Pelotas, RS, Brasil
}

Among the sap-sucking insects that infest sugarcane [Saccharum spp. (Poaceae)] around the world, scale insects (Hemiptera: Coccomorpha) stand out with 103 recorded species. Most of them are frequently regarded as secondary or occasional pests (Garcia Morales et al., 2016). In Brazil, eighteen species of scale insects have already been reported on sugarcane. Of these, Aclerda takahashii (Kuwana, 1932)(Aclerdidae), Margarodes sp., (Margarodidae) and Saccharicoccus sacchari (Cockerell, 1895) (Pseudococcidae) are known to the state of Rio Grande do Sul (Garcia Morales et al., 2016; Borges Filho et al., 2019; Monteiro et al., 2019).

Aclerda takahashii and S. sacchari are monophagous species associated with a small number of host plants of Poaceae. Both are exotic species and distributed in 13 and 79 countries, respectively (García Morales et al., 2016). Populations of these species feed on sugarcane plants by sucking plant sap mainly under overlapping leaf sheaths just below stalk nodes (Cruz et al., 2019).

Saccharicoccus sacchari can also infest the roots of the plant increasing damage and enabling the insect long-lasting permanence in the field. Sugarcane crops heavily infested by this mealybug presented decrease in height, weight and number of internodes on stalks (Mohamed et al., 2009). Losses of sugar due to alteration of juice properties (Atiqui and Murad, 1992) and transmission of the sugarcane baciliform virus (SCBV) are also reported (Autrey et al., 1995; Avellaneda et al., 2001). This is among the most common insects that infest sugarcane crops around the world (Qin et al., 2017), that includes subtropical regions in Brazil (Borges Filho et al., 2019). Additionally, Margarodes spp. are obligatorily hypogeic and less frequently associated with sugarcane in Brazil (Lima, 1950; Jakubski, 1965).

For the first time, Dysmicoccus boninsis Kuwana, 1909 (Hemiptera: Pseudococcidae) was recorded infesting sugarcane in the state of Rio Grande do Sul, Brazil. It also recorded a larger infestation percentage than $S$. sacchari.

This evaluation was carried out in an area of $1.5 \mathrm{ha}$ planted with a local variety of sugarcane in the municipality of São Valentin (27³2'33"S; 52 33'13"W) in the state of Rio Grande do Sul, in August 2018. The sample area was divided into three equal plots according to different year of harvesting (ratoons). Forty stalks were examined in each plot. The stalk samples were taken 5 meters apart from the edges to the center of the crop. All stalk nodes (infested and non-infested by scale insects) were counted in order to calculate the index of infestated nodes $(\%)=[$ (number of nodes with scale insects/ number of nodes) ${ }^{*} 100$ ).

Samples of scale insects were kept in tubes containing $75 \%$ ethanol and mounted on microscope slides following the method described by Granara de Willink (1990). Later, they were identified according to morphological features of the adult female as described by Granara de Willink (2009) and Zhang et al. (2018). Voucher specimens of all species of scale insects studied were deposited in the Coleção de Referência de Insetos e Ácaros - CRIA(Insects and Mites Reference Collection) at the Department of Plant Protection [FCAV/UNESP].

Scale insects were found in all three sample plots infesting $35 \%, 45 \%$, and $70 \%$ of the sugarcane stalks. The index of infested nodes was $4.9 \%, 5.2 \%$, and $11.2 \%$, respectively. Later, specimens appropriate for morphological identification (not injured during evaluation steps) were collected $(\mathrm{n}=128)$ and $72 \%$ were identified as $D$. boninsis that was present in all plots with $100 \%, 94.6 \%$ and $6 \%$ of the scale insects collected in the areas 1,2 and 3, respectively. S. sacchari was present in plots 2 (5.4\%) and 3 (94\%).

In the field, these pseudococcids can be easily differentiated by body color and the number of lateral wax filaments of the female adult. Dysmicoccus boninsis, widely known as "Gray sugarcane mealybug", presents a grayish body with 4 to 6 short lateral filament pairs. The posterior pair is longer and thicker. S. sacchari, known as "Pink sugarcane mealybug", has a pinkish body and does not usually present lateral wax filament pairs. A short posterior pair of wax filaments may be visible in newly mature adult females (for visual details see Miller et al., 2014).

Dysmicoccus boninsis was recorded in 60 countries around the world, from a wide range of grasses and other eleven plant families (Garcia Morales et al., 2016). On sugarcane, Beardsley (1960) mentioned this mealybug as a common pest in Hawaii. According to Bartlett (1978), it is a minor pest in the USA; however, it may cause the death of young shoots when this species is associated with ants.

*e-mail: vsturza27@yahoo.com.br

Received: April 27, 2020 - Accepted: September 1, 2020

This is an Open Access article distributed under the terms of the Creative Commons Attribution License, which permits unrestricted use, distribution, and reproduction in any medium, provided the original work is properly cited. 
More recently, $D$. boninsis was reported infesting stalks and roots of sugarcane in Colombia (Caballero et al., 2017). Despite a lack of information about this pest status in Brazil, $D$. boninsis has been reported on stalks and roots of sugarcane in Northeast and Southeastern states such as Pernambuco, Bahia, Espírito Santo, Rio de Janeiro, Minas Gerais, and São Paulo (Silva et al., 1968; Culik and Gullan, 2005; Culik et al., 2007). This study recorded a high infestation of $D$. boninsis in sugarcane for the first time in Brazil. Moreover, its simultaneous occurrence with S. sacchari had not been recorded before.

More information on $D$. boninsis is required for subtropical conditions of Brazil mainly because it is a polyphagous and hypogeic facultative sugarcane species and this implies high survival chances in crop areas and outbreaks under favorable conditions. Moreover, implications of the coexistence with $S$. sacchari in crop areas require further investigation for commercial genotypes available for growers.

\section{Acknowledgments}

The authors thank Fernando Mezalira and his family for allowing the evaluation of sugarcane fields and Delmir Nadal for supporting field evaluations.

\section{References}

ATIQUI, M.U.A. and MURAD, H., 1992. Assessment of loss in sucrose content of sugarcane due to sugarcane mealybug, Saccharicoccus sacchari (Ckll). Journal of Insect Science (Ludhiana), vol. 5, no. 2, pp. 196-197.

AUTREY, L.J.C., BOOLELL, S., LOCKHART, B.E.L., JONES, P. and NADIF, A., 1995. The distribution of sugarcane bacilliform virus in various geographical regions. In: B. NAPOMPETH and P. WISARATH, eds. Proceedings of XXI International Society of Sugarcane Technologists, 1995, Bangkok, Thailand. Bangkok: Kasetsart University Press, pp. 527-541.

AVELLANEDA, M.C., DIAZ-GRANADOS, C., ANGEL, J.C. and VICTORIA, J., 2001. Transmisión del virus baciliforme de la caña de azúcar (Sugarcane Bacilliform badnavirus ScBV) empleando Saccharicoccus sacchari como vector. In: Proceedings of the Cenicaña XXII Congreso de la Asociación Colombiana de Fitopatología y Ciencias Afines, 2001, Medellín. Cali, Colombia: ASCOLFI, pp. 48.

BARTLETT, B.R., 1978. Pseudococcidae. Introduced parasites and predators of arthropod pests and weeds: a world review. Washington: Agricultural Research Service, United States Department of Agriculture, $545 \mathrm{p}$.

BEARDSLEY, J.W., 1960. A preliminary study of the males of some Hawaiian mealybugs (Homoptera: Pseudococcidae). In: Proceedings of the Hawaiian Entomological Society, 1960, Honolulu. Honolulu: Hawaiian Entomological Society, vol. 17, no. 1959, pp. 199-243.

BORGES FILHO, R.C., STURZA, V.S., BERNARDI, D., DA CUNHA, U.S., PINTO, A.S., DOS ANJOS E SILVA, S.D. and NAVA, D.E., 2019. Population dynamics of pests and natural enemies on sugar cane grown in a subtropical region of Brazil. The Florida Entomologist, vol. 102, no. 3, pp. 526-530. http://dx.doi. org/10.1653/024.102.0313.

CABALLERO, A., RAMOS-PORTILLA, A.A. and KONDO, T., 2017. Scale insects (Hemiptera: Coccomorpha) on sugarcane in Colombia, with description of a new species of Tillancoccus Ben-Dov
(Coccidae).Zootaxa, vol. 4258, no. 5, pp. 490-500. http://dx.doi. org/10.11646/zootaxa.4258.5.6. PMid:28609908.

CRUZ, M.A., PERONTI, A.L.B.G., MARTINELLI, N.M., COSTA, V.A. and IGNÁCIO, G.P., 2019. Complex of natural enemies associated with scale Insects (Hemiptera: Coccomorpha) on sugarcane in Brazil. The Journal of Agricultural Science, vol. 11, no. 4, pp. 1-16. http://dx.doi.org/10.5539/jas.v11n4p160.

CULIK, M.P. and GULLAN, P.J., 2005. A new pest of tomato and other records of mealybugs (Hemiptera: Pseudococcidae) from Espírito Santo, Brazil. Zootaxa, vol. 964, no. 1, pp. 1-8. http:// dx.doi.org/10.11646/zootaxa.964.1.1.

CULIK, M.P., MARTINS, D.S., VENTURA, J.A., PERONTI, A.L.B.G., GULLAN, P.J. and KONDO, T., 2007. Monophlebidae (Hemiptera: Coccoidea) of Coccidae, Pseudococcidae, Ortheziidae, and Monophlebidae (Hemiptera: Coccoidea) of Espírito Santo, Brazil. Biota Neotropica, vol. 7, no. 3, pp. 61-65. http://dx.doi. org/10.1590/S1676-06032007000300006.

GARCÍA MORALES, M., DENNO, B.D., MILLER, D.R., MILLER, G.L., BEN-DOV, Y. and HARDY, N.B., 2016. ScaleNet: a literaturebased model of scale insect biology and systematics. Database, vol. 2016, bav118. http://dx.doi.org/10.1093/database/bav118.

GRANARA DE WILLINK, M.C., 1990. Conociendo nuestra fauna I. Superfamilia Coccoidea (Homoptera: Sternorhyncha). Tucumán: Facultad de Ciencias Nauturales e Instituto Miguel Lillo, Universidad Nacional de Tucumán, Serie Monográfica y Didáctica, no. 6, pp. 43.

GRANARA DE WILLINK, M.C., 2009. Dysmicoccus de la Región Neotropical (Hemiptera: pseudococcidae). Revista de la Sociedad Entomológica Argentina, vol. 68, no. 1-2, pp. 11-95.

JAKUBSKI, A.W., 1965. A critical revision of the families Margarodidae and Termitococcidae (Hemiptera, Coccoidea). London: Trustees of the British Museum (Natural History), 187 p.

LIMA, A.C., 1950. Nova espécie do Margarodes do Brasil (Coccoidea, Margarodidae). Memorias do Instituto Oswaldo Cruz, vol. 47, no. 1-2, pp. 241-248. http://dx.doi.org/10.1590/S007402761949000100009.

MILLER, D., RUNG, A., PARIKH, G., VENABLE, G., REDFORD, A.J., EVANS, G.A. and GILL, R.J., 2014 [viewed 21 April 2020]. Scale insects [online]. 2nd ed. USA: USDA/APHIS/Identification Technology Program (ITP). Available from: http://idtools.org/id/scales/

MOHAMED, G.E.-D., IBRAHIM, S. and MOHARUM, F., 2009. Effect of Saccharicoccus sacchari (Cockerell) infestation levels on sugarcane physical and chemical properties. Egyptian Academic Journal of Biological Sciences, vol. 2, no. 2, pp. 119-123. http:// dx.doi.org/10.21608/eajbsa.2009.15434.

MONTEIRO, G.G., WOLFF, V.R.S., PERONTI, A.L.B.G., MARTINELLI, N.M. and ANJOS, I.A., 2019. First record of Hemiberlesia musae Takagi \& Yamamoto, 1974 and Duplachionaspis divergens (Green, 1899) (Hemiptera: Diaspididae) on sugarcane in greenhouse in Brazil. The Journal of Agricultural Science, vol. 11, no. 2, pp. 392-396. http://dx.doi.org/10.5539/jas.v11n2p392.

QIN, Z., WEI, J., SONG, X., LUO, Y., LIU, L. and DENG, Z., 2017. Efficacy of the ladybird beetle Cryptolaemus montrouzieri Mulsant for control of Saccharicoccus sacchari (Cockerell). Sugar Tech, vol. 19, no. 6, pp. 599-603. http://dx.doi.org/10.1007/s12355017-0528-4

SILVA, A.G.D’A., GONÇALVES, C.R., GALVÃO, D.M., GONÇALVES, A.J.L., GOMES, J., SILVA, M.N. and SIMONI, L., 1968. Quarto catálogo dos insetos que vivem nas plantas do Brasil, seus parasitos e predadores. Rio de Janeiro: Ministério da Agricultura, 622 p. Parte II, $1^{\circ}$ tomo. Insetos, hospedeiros e inimigos naturais.

ZHANG, J.T., WU, B. and WU, S.A., 2018. A review of the genus Saccharicoccus Ferris, 1950 (Hemiptera: Coccomorpha: Pseudococcidae) in China, with description of a new species. Zootaxa, vol. 4375, no. 1, pp. 127-135. http://dx.doi.org/10.11646/ zootaxa.4375.1.7. PMid:29689784. 